\title{
THE USE OF HORROR STORY IN IMPROUING STUDENTS' READING COMPREHENSION FOR ELEVENTH GRADE AT SMAN 3 SINJAI
}

\author{
Muthaharah Basri \\ Universitas Islam Negeri Alauddin Makassar \\ Rara.rt78@gmail.com \\ Mardianah \\ Universitas Islam Negeri Alauddin Makassar \\ mardiana@uin-alauddin.ac.id \\ M. Rusdi \\ Universitas Islam Negeri Alauddin Makassar \\ rusdi@uin-alauddin.ac.id
}

Doi: 10.24252/elties.v\%vi\%i.11394

\begin{abstract}
This research was aimed at investigating how the horror story was use in the reading class to improve the students' reading comprehension of the eleventh grade at SMAN 3 Sinjai. The variables of this research were Horror Story as an independent variable and Reading Comprehension as a dependent variable. The method used in this research was Quasi Experimental research. There were two classes used as the subject in this research; MIA 3 as experimental class and MIA 2 as controlled class. The total population of this research was 186 students taken from the eleventhgrade students of SMAN 3 Sinjai. The total sample of this research was 40 students. The sample was chosen purposively. The instrument of this research was an essay test which was given both in pre-test and post-test. The result of the research shows that the students' performance in pre-test was better compared to that in post-test. In experimental class, the mean score of pre-test was 74.9 (good) and the mean score of post-test was 87.7 (excellent). While in controlled class, the mean score of pre-test was 68.55 (fair) and the mean score of post-test was 77.85 (good). While both of the classes are improved, the significant improvement was occurred in experimental class from fair to very good score. Besides, in controlled class the improvement was only from fair to good score. In addition, the t-test value (2.23) was higher than t-table value (2.024). Based on the findings, the researcher concluded that the implementation of Horror Story was effective to enhance the students' reading comprehension in the eleventhyear students of SMAN 3 Sinjai in academic year 2018/2019. This story makes the students learn with fun and directly involve in classroom activities.
\end{abstract}

Keywords: Horror Story; Students’ Reading Comprehension. 


\section{Volume 2 Number 01, September 2020}

\section{INTRODUCTION}

Reading is one of the language skills which is very important to learn by students. Reading is an appropriate means as a process of mental or cognitive in which a reader should be able to follow and respond to the message of the author. Reading can be used to build a concept, develop vocabulary, give knowledge, add personal enrichment process, develop intellect, help understand and understand the problems of others, develop self-concept and as a pleasure.

The fundamental goal of reading activities is to enable the students to read scientific text. For Indonesian students this is the bridge to understand scientific they are required to read. In senior high school, the students learn about different types of text, including procedure, recount, news, and narrative texts.

Narrative text is interesting text and the students can learn from it. The Narrative text is a story that is created in constructive form. A narrative is commonly found in fiction. Mislaini (2015), in her research, said that the purpose of narrative text is to entertain, to tell a story or to provide literary experience.

As citizens of Indonesia, the people may need to know the fact that in 2013 as a study has revealed that the reading interest in Indonesia is still low, it is only 0.01 and the other countries get 0.45 and 0.62 . Some steps and tips can help to improve the students' reading interest as well as and to increase their reading comprehension; one of them is presenting new text genres, in hope that the students will find the reading class more interesting and enjoyable. In order to be able to increase the score in reading tests, students need to be able to enjoy the process of reading. In other words, they have to be interested in reading itself. Dr. Glenn Walters said that horror story has many surprises that make someone interested to read it, so the researcher chose this story to make the students interested in reading class. Another reason why the researcher chose the horror story because the researcher never found this kind of the story in the reading class and there is no previous research about the type of the story.

Based on the explanation above, the researcher conducted a research draft of thesis entitle The Use of Horror Story in Improving Students' Reading Comprehension for Eleventh Grade at SMAN 3 Sinjai.

\section{The Nature of Reading}

According to Syatriana (2010), reading process includes three processes, the first is letter and word, the second is comprehension of concepts, and the last is reaction and assimilation of the new knowledge with the reader's past experience. It means, the reader must be to know how to analyze in the reading process. 
Based on Tarigan (2008), reading is a process in which done by reader to get message or information from the researcher through printed media. It is very complex process in recognizing and comprehending written symbols which influenced by perceptual skill, decoding, experiences, language background, mind set and reasoning of reader.

Nursam (2009), reading is the interaction between the reader and the writer where the reader tackles what the writer means. The writer expresses it by giving attention, encoding, and retrivied with eyes and brain.

According to Carrel (1988), "reading is not passive but rather than active process. It is an active cognitive process of interacting print media in which monitory comprehension to build up meaning". Moreover, Rahmatullah (2013) states that reading is the meaningful interpretation of printed or written verbal symbols. This activity is not simply looking. It is involves deriving meaning from printed words. It requires a high level of muscular coordination. The reader is not only seeing and identifying the symbols, but also understanding the meaning.

\section{Reading Comprehension}

Tarigan (2008) said that reading is a process in which done by reader to get message or information from the researcher through printed media. It is very complex process in which recognize and comprehend written symbols are influenced by perceptual skill, decoding, experiences, language background, mind set and reasoning of reader.

Comprehension has same meaning with understanding. It is capability to grasp meaning in a text and also the researcher's idea. It is readers' ability to understand the author's message which is influenced by their background knowledge in the topic given by the text. According to Hornby (1995), "comprehension is meant and has excessive aimed in improving or testing one's understands of a language whether written or spoken". Comprehension is not only need in student's reading activities, but also to measure the ability of each student in classroom.

Based on Antoni in Mislaini (2015) states reading comprehension a process that involves the orchestration of the readers' prior knowledge about the world and about language.

Carrel (1988) states that "reading comprehension in general view is the resulting from the four ways interaction between readers, text, task, and structured activity. The success of this interaction depends of the availability of quality of content and strategic schemata to new problem-solving situation. Moreover, reading comprehension is the process of simultaneously extracting and constructing meaning through interaction and involvement 
with written language. It entails three elements: the reader who is doing the comprehending, the text that is to be comprehended, and the activities.

In short, reading comprehension is the act of understanding what readers are being read. It is an intentional, active, interactive process that occurs before, during and after a person reads a particular piece of writing. Without comprehension, reading is nothing more than tracking symbols on a page with eyes and sounding them out.

People read for many reasons but understanding is always a part of their purpose. Reading comprehension is very important because without reading comprehension reading does not provide the reader with any information.

\section{Horror Story as a Part of Narrative}

Mark and Kathy Anderson stated that Narrative is a text that tells a story and, in doing so, entertains the audience. Also, it is narrative text purpose is mainly to inform often contains large passage arranging the events in a story strictly in chronological order. Narrative can be imaginary or factual (fairy tales, mysteries, fables, romances and adventure stories, horror and legends). Many different types of narrative namely humor, romance, crime, real life fiction, historical fiction, horror, fantasy, Science fiction, diary novel, and adventure.

Steve Denning in Butcher (2006) defines narrative as having meaning and its connection, linking human actions and event into multi-related events, displaying the significance that events have on one another.

From the explanation above, narrative text is a story occurred in past time which its social function is to assume or entertain the readers. It is written with cer tain characteristics and its language features.

Tilley (2012) said that horror story or ghost story is a story in which the focus is on creating a feeling of fear. In cultures all over the world, ghost stories have been told and passed down orally from generation to generation. These stories reflect the superstitious fears and beliefs that people had in various cultures. Story about witches, ghosts, goblins, vampires, werewolves and all sorts of land and sea monsters came out of the oral tradition of storytelling.

This story is a part of narrative text so the general structure of this text same with the generic structure with another story in narrative text. The generic structure of narrative is orientation, complication, resolution and coda or reorientation. 


\section{METHOD}

The researcher applied quasi-experimental design with the non-equivalent control group design. It consisted of an experimental class and control class. The experimental group had given pre-test, receive the treatment, and post-test, therefore, the control group used pre-test and post-test.

The population of this research is the second-grade students of SMAN 3 Sinjai and the total of the population is 186 students. The sample of this research was chosen by using purposive sampling. The researcher took a sample of 40 students, which was divided into two classes: 20 students were in the experimental class and the other 20 students were in the control class. The researcher used purposive sampling to select the participants that are appropriate for the focus of the research. The data of the students reading scores was obtained from the teacher. The researcher used the data to determine the research sample.

The instrument of this research was a reading test. The reading test was given in both pre-test and post-test. The test consisted of 25 short answer tests. The purpose of using the short answer test was to measure the students' comprehension of the reading materials given by the researcher.

\section{FINDINGS AND DISCUSSIONS}

\section{Findings}

\section{The Classification of the Students' Pre-Test and Post-Test Score in Experimental} Class.

The distribution of frequency and percentage of pre-test score in experimental class (Table 1)

\begin{tabular}{|c|c|c|c|c|}
\hline No & Classification & Score & Frequency & Percentage \\
\hline 1 & Excellent & $91-100$ & - & - \\
\hline 2 & Good & $76-90$ & 14 & $70 \%$ \\
\hline 3 & Fair & $61-75$ & 4 & $20 \%$ \\
\hline 4 & Poor & $51-60$ & 1 & $5 \%$ \\
\hline 5 & Very Poor & Less than 50 & 1 & $5 \%$ \\
\hline & Total & & 20 & $100 \%$ \\
\hline
\end{tabular}

The table shows the rate percentage score of experimental class from 20 students in the pre-test. From the table, it can be concluded that there were 14 students (70\%) obtained good 
scores, while the others obtained lower scores. In fact, no students could reach the excellent score.

The distribution of frequency and percentage of post-test score in experimental class (Table 2)

\begin{tabular}{|c|c|c|c|c|}
\hline No & Classification & Score & Frequency & Percentage \\
\hline 1 & Excellent & $91-100$ & 10 & $50 \%$ \\
\hline 2 & Good & $76-90$ & 8 & $40 \%$ \\
\hline 3 & Fair & $61-75$ & 1 & $5 \%$ \\
\hline 4 & Poor & $51-60$ & 1 & $5 \%$ \\
\hline 5 & Very Poor & Less than 50 & - & \\
\hline & Total & & 20 & $100 \%$ \\
\hline
\end{tabular}

The table above shows the rate percentage score of experimental class from 20 students in the post-test. In the table above, there were 10 students (50\%) who obtained the excellent scores, while the other 10 students obtained either good or poor scores. However, no one got the very poor score.

\section{The Classification of the Students' Pre-Test and Post-Test Score in Controlled Class.}

The distribution of frequency and percentage of pre-test score in controlled class (Table 3)

\begin{tabular}{clccc}
\hline $\mathbf{N o}$ & Classification & Score & Frequency & Percentage \\
\hline $\mathbf{1}$ & Excellent & $91-100$ & - & - \\
\hline $\mathbf{2}$ & Good & $76-90$ & 7 & $35 \%$ \\
\hline $\mathbf{3}$ & Fair & $61-75$ & 8 & $40 \%$ \\
\hline $\mathbf{4}$ & Poor & $51-60$ & 3 & $15 \%$ \\
\hline $\mathbf{5}$ & Very Poor & Less than 50 & 2 & $10 \%$ \\
\hline & & & & $\mathbf{1 0 0 \%}$
\end{tabular}

Table 3 above shows the rate percentage score of control class from 20 students in the pre-test. In the table, most of the students obtained fair score (40\%), and no one got the excellent score.

The distribution of frequency and percentage of post-test score in experimental class (Table 4)

\begin{tabular}{|c|c|c|c|c|}
\hline No & Classification & Score & Frequency & Percentage \\
\hline 1 & Excellent & $91-100$ & 2 & $10 \%$ \\
\hline 2 & Good & $76-90$ & 10 & $50 \%$ \\
\hline
\end{tabular}


Basri, Mardiana, Rusdi, The Use of Horror Story...

\begin{tabular}{|c|c|c|c|c|}
\hline 3 & Fair & $61-75$ & 6 & $30 \%$ \\
\hline 4 & Poor & $51-60$ & 2 & $10 \%$ \\
\hline 5 & Very Poor & Less than 50 & - & - \\
\hline & & & 20 & $100 \%$ \\
\hline
\end{tabular}

Table 4 shows the rate percentage score of control class from 20 students in the post test. There were $2(10 \%)$ students who could reach excellent score, and the most of students obtained good score $(50 \%)$.

Based on the result above, it can be concluded that the students' scores in the post-test were higher than those in the pre-test. Therefore, there was an improvement. It can be seen in the table 4.3 and 4.4 .

\section{The Mean Score and Standard Deviation of pre-test and post-test in Experimental and Control Class}

The mean score and standard deviation of pre-test and post-test in experimental and control class

\begin{tabular}{lrrrr}
\hline \multirow{2}{*}{ Class } & \multicolumn{2}{c}{ Pre-Test } & \multicolumn{2}{c}{ Post-Test } \\
\cline { 2 - 5 } & Mean Score & $\begin{array}{c}\text { Standard } \\
\text { Deviation }\end{array}$ & Mean Score & $\begin{array}{c}\text { Standard } \\
\text { Deviation }\end{array}$ \\
\hline Experimental & 74.9 & 8.04 & 87.7 & 15.43 \\
\hline Controlled & 68.55 & 12.45 & 77.85 & 12.25
\end{tabular}

The table above shows that, the mean score of the experiment class in pre-test was 74.9 and the standard deviation of the experiment class was 8.04, and the mean score of the control class in pre-test was 68.55 and the standard deviation of the control class was 12.45 . While the mean score of the experiment class in post-test was 87.7 and the standard deviation of the experiment class was 15.43 , and the mean score of control class in post-test was 77.85 and its standard deviation was 12.25 .

It can be concluded from both of the tests that the experiment class obtained greater mean score in the post test than that in the control group. The significant score between experiment and control class can be known by using t-test.

The result of t-test can be seen in table 6 as following table:

\begin{tabular}{ccc}
\hline Variable & t-test value & $\begin{array}{c}t- \\
\text { table value }\end{array}$ \\
\hline Post-test & 2.23 & $\mathbf{2 . 0 4 2}$ \\
\hline
\end{tabular}


The t-table above indicates that the t-table was smaller than the t-test value. The result of the test shows that there was a significant difference between the t-test and the t-table $(2.23>$ 2.042), the researcher concluded that t-test value was higher than t-table. The result of the $t-$ test statistical analysis shows that there was a significant difference between the experimental class and the control class. The statement was proved by the t-test value (2.23) which was higher than the t-table value (2.042), at the level of significance 0,05 and the degree of freedom $\left(\mathrm{N}_{1}+\mathrm{N}_{2}\right)-2=(20+20)-2=38$.

From the result above, it shows that the difference between t-test and t-table was high enough. It could be concluded that using horror story was effective on the eleventh-grade students to increase the students' reading comprehension at SMAN 3

Sinjai.

\section{DISCUSSION}

The result of this study showed that the students' scores were much higher after the treatment using Horror Study in the experimental class. The reading comprehension of the students was improved by using Horror story in reading class. Most of them were in excellent and very good score. Horror story is a type of narrative text which focuses on creating a feeling of fear. Such tales are of ancient origin and from a substantial part of the body of folk literature. They can feature supernatural element such as ghosts, witches, or vampires, or they can address more realistic psychological fears. Horror Story is a new genre for the students because horror story had never been applied in the class before this study was conducted.

Most of the students agreed that using horror story to improve their reading comprehension was good choice, because the students found the English class more interesting. For the students to learn English by using horror story is not monotonous and this kind of the story is something new for them. Narrative text is a part of authentic material that can be used to increase the motivation of the students in learning. It is supported by Nuttall in Apsari (2014) who states that "authentic texts can be motivating because they are proof that the language is used for real-life purposes by real people". This is also evidenced through a research conducted by Alwi. In her research she concluded that the use of horror story as the part of narrative text can improve the students' reading motivation.

Furthermore, the horror story can be used to learn the language, especially in developing reading skill. Students can get new information based on their story line. Furthermore, that-the learning by using horror story for the students can add knowledge, add 
insight. In addition, whenever the students find unfamiliar words, they will search the meaning of the words in the dictionary. The students will have the opportunity to gain new vocabulary and to develop their reading comprehension. Therefore, in learning reading comprehension is important; caused the students in learning English will not be able to express their ideas inadequate good interaction and communication with one another without having the board understanding.

Briefly, reading comprehension of the experimental class had proven that Horror Story could be beneficial in improving students' reading comprehension. It can be seen from the significant improvement of the students' fluency and accuracy from the pre-test to the posttest. The same result as the previous related research, Mislaini (2015) concludes that implementation of fable can improve the students' reading comprehension.

According to the result of this research, the effectiveness of using Horror Story toward students' reading comprehension can be explained in two points. First, Horror Story encouraged students to open their dictionary. It happened because horror story was something new for them and contained many unfamiliar words that they wanted to know. Fortunately, students' vocabulary will increase. It allowed the students to gain new vocabulary and to train the students to look up new words in a dictionary. As we know that using dictionary can make the students' long-time memory be active.

Second, Horror Story guided the students to enjoy their class. As the researcher know that Horror Story is a new thing at the reading class, so it can make the students interested and enjoy their class. The students' interest is very important to increase their reading comprehension. Without their interest in reading class it will be hard to increase their reading comprehension.

In summary, the researcher asserted that Horror Story is one of the various stories that useful in teaching reading. There were many facts based on scientific research that make Horror Story in teaching reading was effective.

\section{CONCLUSION}

Teaching reading by using Horror Story was able to improve the students' reading comprehension of the Eleventh Grade Students of SMAN 3 Sinjai. The mean score of Experimental Class in pre-test is 74.9 and in the post-test 87.7 while the mean score of Controlled Class in pre-test is 68.55 and in the post-test 77.85 . Teaching reading by using Horror Story to the Eleventh Grade Students of SMAN 3 Sinjai was improved significantly. It means that the research hypothesis $\left(\mathrm{H}_{1}\right)$ was accepted. It can be seen from the significant improvement of the students' fluency and accuracy from the pre-test to the post-test. The 
improvement can be seen from the statistical analysis that t-test (2.23) was higher than t-table value (2.042).

\section{REFERENCES}

Al-Azri, R. H and Al-Rashdi, M. H.(2014). The Effect Of Using Authentic Materials In Teaching.International journal of scientific \& technology research,2(4)2277-8616.

Al-Qur'an dan Terjemahannya. Departemen Agama RI. Bandung: Diponegoro. 2008

Alwi A, The use of Humor Story to Improve Students' Motivation Reading Comprehension. 2003.

Anderson and Pearson. Teaching Reading. Third edition. Boston: Houghton Miffln Company. 1984.

Anderson, Mark and Kathy Anderson, Text Types in English 3, South Yarra:Mcmillan,1998.

Apsari Y. The Use of Materials in Teaching Reading Comprehension. ELTIN Journal, Vol 2/II, October 2004.

Arikunto, S. Prosedur Penelitian. Jakarta: Rineka Cipta. 2013.

Berado, S. A. The Use of Authentic Materials in the Teaching of Reading. The Reading Matrix Journal Vol.6 No.2, September 2006.

Brown, H. D. Principle of language teaching and learning. Engel Word Cliffs,NJ: Prentice Hall. 2003.

Brown, H. Douglas. Analytic scale for rating composition tasks. Principles and Classroom Practice. 1984.

Buthcer E. Susan. Narrative as Teaching Strategi. The Journal of Correction Education vol.57(3). September 2006.

Carrel, P. Interactive approach to second language reading. New York: Cambridge University Press. 1998.

Duke, Nell K., and P. David Pearson. How Can I Help Children Improve Their Comprehension? Ann Arbor, Michigan: Center for the Improvement of Early ReadingAchievement (CIERA), Michigan State University, 2001.

Gay, L.R. Education Research: Competencies for Analysis and Application. 8thn Education. United State: Earson Merrill Prenfile Hall. 2006.

Hanifah Ramli. The Effectiveness of Authentic Materials in Teaching Reading Comprehension to the Second Year Students of SMA Negeri 1 Pangkep Regency. Makassar : State University Makassar. 2004.

Harris, D. Testing English as A Second Language. New York: Mc. Graw Hill Book Company. 1969. 
Hasanah, U. Novia, Improving Students' Reading Comprehension in Narrative Texts with the Medium of Story Map (A Classroom Action Research at the Eighth Grade of SMP Nurul Islam Semarang in the Academic Year of 2015/2016. 2016.

Heaton, J. B. Writing English Language Tests. London: Longman, 1997.

Hidayat, S, N. Improving Students' Interpersonal Conversation Competence By Utilizing Cooperative Learning Through Inside - Outside Circle (IOC) Learning Method at The Second Semester Students of PIBA Program of UIN Alauddin Makassar. Undergraduate Thesis. Alauddin Makassar. 2013.

Hornby, A. S. Oxford advanced learners dictionary current English. London: Oxford University Press. 1995.

Jacobson Eril etc, Creating Materials and Activities for the Adult Literacy Classroom, Michigan: LPALS, 2003.

Klingner, Janette K. Sharon Vaughn and Alison Boardman, Teaching Reading Comprehension to students with Learning Difficulties, London : The Guilford Press, 2007.

Kunandar, Penilaian Hasil Belajar Peserta Didik. Jakarta : Raja Grafindo Persada. 2013.

Mamo, K. The Use of Authentic Materials in Teaching Listening Skill to College Students: The Cause of Bonga College of Teaching Education. 67 Addis Ababa University, Ethiopia. 2013

McNamara, R. Reading Comprehension Strategies, Theories, Interventions, and Technologies. New Jersey: Laurence Erlbaum Association. 2007.

Mislani, Improving Students' Reading Comprehension of Nature Text by Using Fable at the Grade X SMAN 1 Bonai Darussalam.x. 2015.

Nasir, S.H. Improving Students' Interpersonal Conversation Competence By Utilizing Cooperative Learning Through Inside - Outside Circle (IOC) Learning Method at The Second Semester Students of PIBA Program of UIN Alauddin Makassar. undergraduated thesis. Makassar: UIN Alauddin Makassar. 2013.

Nursam. Improving Reading Comprehension of the Students Through the Implementation of SNIPS and PRSR Srategies. Thesis. Makassar: English Department of Tarbiyah Faculty UIN Alauddin Makassar. 2009.

Rahmatullah. Improving reading comprehension through inquiry method for the second grade students of multimedia department in SMKN 1 Kopang in the academic year 2012-2013. Unpublished undergraduate thesis, Hamzanwadi Selong College of Teacher Training and Education, Nusa Tenggara Barat, Indonesia. 2013. 
Rusdy, Muhammad. Inreasing the Third Year Students' Reading Comprehension toward English Textbooks at the Language Department of MAS An-Nahdlah Makassar by Using SQ3R Technique. Thesis. Makassar: UIN Alauddin Makassar. 2005.

Saleh, M. Pengantar Praktik Penelitian Pengajaran Bahasa. Semarang: IKIP Semarang Press. 2001.

Sudjana. Strategi Pembelajaran. Bandung: Falah. 2010.

Sugiyono. Metode Penelitian Pendidikan. Bandung; Alvabeta CV. 2016.

Syatriana, Developing a Model of Teaching Reading Comprehension for Efl Students. Universitas Negeri Makassar, Indonesia. 2010.

Tarigan, H. G. Membaca sebagai suatu keterampilan berbahasa. Bandung: Angkasa. 2008.

Tilley A. Using Short Stories in the English Classroom. NET Section. 2012.

Tindall Evie and Nisbet Deanna. Exploring the Essential Components of Reading. Journal of Adult Education. Information Series, No.1 Vol. 39. 2010.

Tunde-Awe, B. M. EFL Adult Learners' Reading Attitude and Reading Comprehension: A Preliminary Study. Journal, No.7 Vol.5. 2015.

Yamashita, J. Mutual compensation between L1 reading and L2 language Proficiency in L2 reading comprehension. Journal of Research in Reading. 2002. 